\title{
The Local Impact of Indonesian Workers Migration: A Special Case at Ponorogo Regency
}

\author{
Bambang Widiyahseno $^{1}$, Rudianto ${ }^{2}$, Ida Widaningrum ${ }^{3}$ \\ Faculty of Social and Political Sciences, Universitas Muhammadiyyah Ponorogo, Ponorogo, \\ Indonesia $^{1,2}$ \\ Institute for Research and Public Services, Universitas Muhammadiyyah Ponorogo, Ponorogo, \\ Indonesia $^{3}$ \\ \{bbwidiyahseno@umpo.ac.id ${ }^{1}$, alrujikar@gmail.com ${ }^{2}$, iwidaningrum@yahoo.ac.id $\left.{ }^{3}\right\}$
}

\begin{abstract}
Many people from the high populated developing country migrate to the developed country in order to find the higher salary jobs. Indonesia is one of the Asian country sending a lot of workers abroad. The number of the migrant workers from Ponorogo regency is the seventh largest in Indonesia and the highest in East Java Province. Therefore, some positive and negative impact are found in Ponorogo related to migrant workers, including the economic impacts and family issues. It has been found from the previous researches that the migrant workers give the positive impact on the economic improvement in Ponorogo regency. However, the negative issues also arise in the family life of the migrant workers, such as the lack attention of their children and the high number of divorce lawsuits. Many people from the high populated developing country migrate to the developed country in order to find the higher salary jobs. Indonesia is one of the Asian country sending a lot of workers abroad. The number of the migrant workers from Ponorogo regency is the seventh largest in Indonesia and the highest in East Java Province. Therefore, some positive and negative impact are found in Ponorogo related to migrant workers, including the economic impacts and family issues. It has been found from the previous researches that the migrant workers give a positive impact on the economic improvement in Ponorogo regency. However, the negative issues also arise in the family life of the migrant workers, such as the lack of attention of their children and the high number of divorce lawsuits.
\end{abstract}

Keywords: Migrant Workers, Ponorogo Regency, Impact, Economic, Family

\section{Introduction}

The international migration of the workers affects the change of the condition of either sending-labor or receiving-labor country. A sending-labor country is usually the high populated country with a less number of job opportunity. The developing country in Southeast Asia such as Indonesia, Vietnam, Filipina, and Thailand are the important sending laborcountry to Taiwan with the total number of migrant workers per August 2017 as many as 156,342 people, 199,546 people, 146,344 people, and 61,001 people, respectively [1]. Otherwise, the less populated countries with the high economic development rate need many 
workers from the sending-labor country. The effect of the globalization makes the migration of international workers much easier. However, the globalization also increases the economic disparity between the sending- and the receiving-labor country [2].

Based on the data from the National Agency for Placement and Caring of Indonesian Migrant Worker (Badan Nasional Penempatan dan Perlindungan Tenaga Kerja Indonesia), abbreviated as BNP2TKI, until the end of August 2017, it has been recorded that East Java province is in the third rank of the highest number of migrant workers after West Java and Central Java. In the BNP2TKI data, it is also shown that Ponorogo regency is in the seventh higher of the number of migrant workers in Indonesia [3].

Some recent articles published in the various international journals have discussed the aims of migrant-workers to find the job abroad [4], the issues in their working countries [5]; [6], and the role of the government agency and NGO in helping the issues of migrant-workers [7]; [8]. However, it is known that the migrant workers departed to the destination countries with the family left in their hometown. The data from BNP2TKI shows that $50 \%$ of migrant workers are married and previously living with their family [3]. This phenomenon motivates us to resume the previous research especially on the issues arising in the hometown of the migrant workers, including the economic impacts and family issues. In this review paper, we discuss the specific issues in Ponorogo as the highest sending-labor regency in East Java province. The international migration of the workers affects the change of the condition of either sending-labor or receiving-labor country. A sending-labor country is usually the high populated country with a less number of job opportunity. The developing country in Southeast Asia such as Indonesia, Vietnam, Filipina, and Thailand are the important sending laborcountry to Taiwan with the total number of migrant workers per August 2017 as many as 156,342 people, 199,546 people, 146,344 people, and 61,001 people, respectively [1]. Otherwise, the less populated countries with the high economic development rate need many workers from the sending-labor country. The effect of the globalization makes the migration of international workers much easier. However, the globalization also increases the economic disparity between the sending- and the receiving-labor country [2].

Based on the data from the National Agency for Placement and Caring of Indonesian Migrant Worker (Badan Nasional Penempatan dan Perlindungan Tenaga Kerja Indonesia), abbreviated as BNP2TKI, until the end of August 2017, it has been recorded that East Java province is in the third rank of the highest number of migrant workers after West Java and Central Java. In the BNP2TKI data, it is also shown that Ponorogo regency is in the seventh higher of the number of migrant workers in Indonesia [3].

Some recent articles published in the various international journals have discussed the aims of migrant-workers to find the job abroad [4], the issues in their working countries [5], [6], and the role of the government agency and NGO in helping the issues of migrant-workers [7]; [8]. However, it is known that the migrant workers departed to the destination countries with the family left in their hometown. The data from BNP2TKI shows that $50 \%$ of migrant workers are married and previously living with their family [3]. This phenomenon motivates us to resume the previous research especially on the issues arising in the hometown of the migrant workers, including the economic impacts and family issues. In this review paper, we discuss the specific issues in Ponorogo as the highest sending-labor regency in East Java province. 


\section{Result and discussion}

\subsection{The Recent Data of Indonesian and Ponorogo Migrant Workers}

Indonesia is one of the largest labor-sending countries in Asia. The data from the BNP2TKI shows that as many as 148,285 migrant workers have been placed abroad from January to August 2017. This number is less by 8,316 people than in the same period in 2016 . The $63 \%$ of the migrant workers are female which has a higher risk than the male workers. Around half of the total migrant workers are married, and their family is left in their hometown for several years of working contract abroad [3]. Some issues may arise after a few months or few years of the migrant worker's departure associated with their families.

Ponorogo regency is located in East Java province with a total population of 868,814 people in 2016. The population density of Ponorogo is around 633 people per $\mathrm{km} 2$. According to the statistics bureau of Ponorogo regency, the number of poor people in 2016 is approximately $11.75 \%$ of the total population. The poverty line was calculated as IDR 266,312 in 2016. This amount is quite low if it is compared with the minimum wage of Ponorogo that is IDR 1,238,000 [9].

Many people decide to find a job abroad mostly are due to economic reasons. The people are motivated to increase their income for their family and future live [10]. This phenomenon also occurs in Ponorogo regency. Many people having a low income decide to seek a job abroad [11]. In January to August 2017, as many as 4,009 people from Ponorogo regency are sent abroad as the migrant workers. This number is in the rank of the seventh highest sendinglabor regency in Indonesia after Lombok Timur, Indramayu, Lombok Tengah, Cirebon, Cilacap, and Subang Regency [3]. Based on data of Statistics Bureau of Ponorogo Regency (2017), most of the migrant workers of Ponorogo choose Taiwan, the Republic of China for their working country in 2016. The second largest destination country of Ponorogo migrant workers is Hong Kong. The number of female migrant workers is three times higher than that one of the male workers. This phenomenon should give the alert to the government of Ponorogo regency to aware and take care of the issues about the matter of migrant workers.

\subsection{The Economic Impact of Migrant Workers Family}

The higher salary in the developed country attracts many Indonesian people to work abroad. The migrant workers aim to improve the economic condition of their family and to increase the amount of their saving for the future. In the year 2016, the total remittance amount of Indonesian migrant workers is around IDR 119,590 billion (Indonesia, BNP2TKI). The amount of remittance from migrant worker entering the Ponorogo regency via the postal transfer reached the amount of IDR 20 billion every month. The number of transaction is normally between 4000 to 5000 processes, even during the Islamic holiday moment (Eid ul Fitr), the number increase until 7000 transactions with the total amount of IDR 27 billion. Migrant workers in Hong Kong dominated the amount of remittance by 60 to 70 percent, and it is followed by the migrant workers in Taiwan and South Korea [12].

Some researchers from the Muhammadiyah University of Ponorogo have studied the economic impact of the family of migrant workers. Khoirurrosyidin has investigated the use of the remittance of migrant workers in Ponorogo regency [13]. Wafirotin has published the result of her investigation on the effect of the migration on the social, economic condition of migrant's family in Babadan district, Ponorogo regency [14]. They found that migrant workers normally improve the economic condition of their family. When some of the members of the 
family with low income decided to find a higher salary job abroad as the migrant workers, they send the excess of the living cost to their family. The amount of money received by the family from the migrant workers is quite big compared with the income of the local job. The use of money from the migrant workers highly depend on their family. That money is mainly used to buy the home appliances, to renovate the house, and to pay the daily expenses [15]. If the amount of the money sent to the family spent in a consumptive way, the migrant worker would not get the benefit from their effort of working abroad. The migrant workers having a good family will spare some amount of the money in the investment type. For example, the migrant workers from Babadan district, Ponorogo regency have the preference to invest their money in the properties sector, e.g. to buy the land and houses. They believed that the price of the properties will always increase all the time, which is kind of low-risk investment [15].[16] [17] The migrant workers usually need more support from the government or NGOs to guide them on how to create the business after returning to their hometown. Therefore, the exmigrant workers can help to improve the economic condition in their home country postmigration [18]. Some ex-migrant workers have created the new business in their hometown, such as farming, convenience shop, car service, beauty salon, higher education for their family, etc. $[15][19]$.

\subsection{The Family Issues of Ponorogo Migrant Workers}

It has been mentioned that around 50 percent of migrant workers have marital status when they decide to find the job abroad. Some issues then show up within their family life. The children of the female migrant workers have a potential problem during their growth period. Sugiarti has found that around 39.2 percent of the children of migrant workers in Sukorejo district, Ponorogo regency shows the dubious growth, while 30.4 percent shows the normal growth and another 30.4 percent shows the abnormal growth [20]. Rohmawati found that there is a positive correlation between parenting method and the social development of the children of migrant workers [21]. Puspitaningrum investigated the good and bad behavior of migrant's children in the age of 7 to 12 years old in Slahung district, Ponorogo Regency [22]. She identified that the children with good behavior appreciate the others and act politely, yet she could not find the children of migrant workers respecting the older and loving the others. The children having bad behavior are easy to angry, hitting the others, saying harshly, and telling a lie. The children of migrant workers in Ponorogo have also been found giving less attention in their personal health such as awareness of the menstruation [23]. Although some negative effects appear during the growth period of the children of migrant workers, however, it has been found by Purwatiningsih that the migrant's children had the wish to find the job abroad as well for the better economy [24].

Another issue that emerged in Ponorogo regency related to migrant workers is the high number of divorces. From January to September 2016, there are 1,670 divorce cases consisting of 1,137 divorce lawsuits from the wife and 533 divorces from the husband. Around 40 percent of the total divorce cases are submitted by female migrant working in Taiwan and Hong Kong [25]. The first motive of divorce is due to economic reasons. The increasing of the economic status of the female migrant workers, e.g., they have a large number of bank deposits and many types of investment, give them the feeling of more superior than their husbands. The partner affair is another motive of the divorce lawsuit case. The affair is usually triggered by the sexual needs of a wife or husband that cannot be released. During the period of working abroad for several years, the female workers live in different places with their husband. In some countries like Taiwan and Hong Kong, the female and the 
male workers have the chance to meet together in public places and often make the conversation about their private lives during the holiday. The sexual needs, feeling alone, and the intimate conversation between the female and the male migrant workers induce the affairs between them. The affairs can also occur in the husband side. The husbands receive a lot of money from the remittance of female workers. With the big amount of money, some husbands find the new partner instead of investing the money or depositing in the bank[26]. The government of Ponorogo City has proposed a residential policy that during the period of working abroad, the Ponorogo migrant workers are not allowed to submit the divorce lawsuit. The government hopes that this policy can minimize the number of divorce cases in Ponorogo regency [27].

\section{Conclusion}

The international migration of the workers affects the change of the condition of either sending-labor or receiving-labor country. Indonesia is one of the largest sending-labor countries. The number of migrant workers from Ponorogo regency is the seventh largest in Indonesia and the highest in East Java Province. Therefore, some positive and negative impact is found in Ponorogo related to migrant workers. The migrant workers give a positive impact on the economic improvement in their hometown. However, the negative issues also arise in the family life of the migrant workers, such as the lack of attention of their children and the high number of divorce lawsuits.

Acknowledgements. This project is funded by the Directorate of Higher Education, Indonesia under the Competitive Research Grant PUPT with the contract No. 120/SP2H/LT/DRPM/IV/2017 in the fiscal year of 2017.

The authors also acknowledge Dr. Rizal Arifin, the head of the Institute for Research and Public Services, Universitas Muhammadiyah Ponorogo for his valuable advice and help during the writing of this paper.

\section{References}

[1] J. A. Jordaan, "Foreign workers and productivity in an emerging economy: The case of Malaysia," Rev. Dev. Econ., vol. 22, no. 1, pp. 148-173, Feb. 2018.

[2] Wicramasekara, "Asian Labour Migration: Issues and Challenges in An Era of Globalization," in International Migration Papers, 2002, vol. 57.

[3] BNP2TKI, "Data Penempatan dan Perlindungan TKI Periode 1 Januari s.d. 31 Agustus 2017," BNP2TKI, 2017. [Online]. Available: http://www.bnp2tki.go.id/read/12943/Data-Penempatan-dan-Perlindungan-TKIPeriode-1-JANUARI-S.D-31-DESEMBER-2017.html.

[4] A. Kaur, "Indonesian Migrant Workers in Malaysia: From Preferred Migrants to 'Last to be Hired' Workers," Rev. Indones. Malaysian Aff., vol. 39, no. 2, pp. 3-30, 2005.

[5] J. Liow, "Malaysia's Illegal Indonesian Migrant Labour Problem: In Search of Solutions," Contemp. Southeast Asia, vol. 25, no. 1, pp. 44-64, 2003.

[6] A. Loveband, "Positioning the Product: Indonesian Migrant Women Workers in Taiwan," J. Contemp. Asia, vol. 34, no. 3, pp. 336-348, 2007.

[7] M. Ford, "Organizing the Unorganizable: Unions, NGOs, and Indonesian Migrant Labour,” Int. Migr., vol. 42, no. 5, pp. 99-119, 2004. 
[8] R. Silvey, "Transnational Domestication: State Power and Indonesian Migrant Women in Saudi Arabia," Polit. Geogr., vol. 23, no. 4, pp. 245-264, 2004.

[9] Bureau of Ponorogo Regency Statistic, Ponorogo Regency in Figures 2017. Ponorogo: Statistic Bureau of Ponorogo Regency, 2017.

[10] M. A. Nasution, Globalisasi \& Migrasi Antarnegara. Bandung: Alumni, 1999.

[11] D. Maulida, "Pengambilan Keputusan untuk Menjadi Tenaga Kerja Indonesia (TKI)." 2012.

[12] RRI Madiun, "Remitansi TKI ke Kantor Pos Ponorogo Capai 20 Milyar," RRI Madiun, 2016. [Online].

Available: http://rri.co.id/madiun/post/berita/302222/ekonomi/remitansi_tki_ke_kantor_pos_pon orogo_capai_rp_20 miliar.html.

[13] Khoirurrosydin, "Pola Aliran Uang Tenaga Kerja Indonesia di Ponorogo," J. Fenom., vol. 5, no. 1, pp. 30-42, 2008.

[14] K. Z. Wafirotin, "Dampak Migrasi Terhadap Kondisi Sosial Ekonomi Keluarga TKI di Kecamatan Babadan Kabupaten Ponorogo," J. Ekuilibirium, vol. 11, no. 2, pp. 1533, 2013.

[15] K. Hamidah, "Dampak Remitansi Tenaga Kerja Indonesia (TKI) Luar Negeri Pada Peningkatan Investasi Daerah Asal,” Ekuilibrium, vol. 8, no. 1, pp. 1-14, 2013.

[16] K. Hamidah, "Investasi Properti sebagai Pilihan Keluarga Tenaga Kerja Indonesia (TKI) di Kecamatan Babadan Kabupaten Ponorogo," in Prosiding Seminar Nasional Hasil-Hasil Penelitian 2016, 2016.

[17] K. Hamidah and U. Farida, "Analisis Prioritas Investasi Keluarga Tenaga Kerja Indonesia (TKI) di Kecamatan Babadan Kabupaten Ponorogo,” Akunt. Dewantara, vol. 1, no. 1, pp. 97-105, 2017.

[18] S. Abas, W. Bambang, and Rudianto, "Model Pemberdayaan TKI Pasca Migrasi Melalui Ekonomi Produktif Menuju Keluarga Sakinah,” Muaddib, vol. 4, no. 1, pp. 119, 2014.

[19] N. Kristiyana and H. Choirul, "Transisi Peran TKI Purna di Ponorogo, dari Buruh Menjadi Wirausahawan dan Tuan Tanah," J. Ekuilibirum, vol. 12, no. 1, pp. 34-45, 2014.

[20] R. Sugiati, Thesis : Perkembangan Anak Pra Sekolah pada Orangtua sebagai TKI di TK Desa Kedung Banteng Kecamatan Sukorejo Kabupaten Ponorogo”. Ponorogo, 2015.

[21] P. D. Rohmawati, "Hubungan Pola Asuh dengan Perkembangan Sosial dan Kemandirian Anak TKW Usia 1-5 Tahun," Universitas Muhammadiyah Ponorogo, Ponorogo, 2015.

[22] E. Puspitaningrum, "Deskripsi Perilaku Moral Anak TKW Usia 7-12 TahunStudi Kasus di Desa Mojopitu Kecamatan Slahung Kabupaten Ponorogo Tahun 2015.” Ponorogo, 2016.

[23] H. Ernawati, "Pengetahuan Menstruasi Remaja yang Mengalami Substitusi Pola Asuh pada Keluarga TKI," in Proceeding at National Seminar, STIKES Aisiyah, 2015.

[24] S. Purwatiningsih, "Renspons Anak-anak Migran Terhadap Migrasi Internasional di Perdesaan Ponorogo," Populasi, vol. 24, no. 1, 2016.

[25] Jateng Tribun, "40 Persen Penyumbang Perceraian di Ponorogo Adalah TKI yang Kerja di Taiwan dan Hongkong," Jateng Tribun, 2016. [Online]. Available: http://jateng.tribunnews.com/2016/10/31/40-persen-penyumbang-perceraian-diponorogo-adalah-tki-yang-kerja-di-taiwan-dan-hongkong.

[26] M. Al Alawi, "Merasa Penghasilan Lebih Tinggi, Banyak TKW Ponorogo Minta 
Cerai," Kompas.com, 2017. [Online]. Available: https://regional.kompas.com/read/2016/10/31/17080531/merasa.penghasilan.lebih.ting gi.banyak.tkw.ponorogo.minta.cerai.

[27] B. M. I. Liputan, "Pemkab Ponorogo Larang TKI Ajukan Gugatan Cerai, Ini Aturannya," Surya Malang, 2016. [Online]. Available: http://suryamalang.tribunnews.com/2016/11/08/pemkab-ponorogo-larang-tki-ajukangugatan-cerai. 